\title{
DEVELOPMENT OF A MOBILE MACHINE FOR PICKING PRICKLY PEAR FRUIT
}

\section{A. M. DRESS ${ }^{(1)}$ and M. M. IBRAHIM ${ }^{(2)}$}

\section{ABSTRACT}

Hand harvesting of prickly pear fruits is greatly inefficient; it is slow and expensive, field conditions are arduous, unsafe and risky. Prickly pear plant is entirely covered with thorns, while fruit has easily detachable microscopic hairs that stuck in bare skin; scaring off untrained workers. A mobile mechanical machine for picking prickly pear fruits was designed, fabricated and evaluated for its performance and technoeconomic feasibility. Some physical and mechanical properties (dimensions, mass, volume, density, static coefficient of friction and shear force) of prickly pear fruits that are pertinent to the mechanical processing were measured and considered by the design of the machine.

The developed machine was evaluated at two power source (mechanical and manual) and mechanical source provides two levels of crank speed (40 and $60 \mathrm{rpm}$ ). The evaluation was based on the following parameters: productivity, fruit damage, consumed energy and picking cost comparing with hand picking.The obtained results of the developed machine gave positive results for evaluation criteria. The productivity increased by $171.4 \%$, minimizes the fruit damage by $42.4 \%$, decreased consumed energy by 13.28 times and decreased picking cost by $29.8 \%$ comparing with hand picking method.

Keywords: prickly pear, picking, mechanical harvest.

\section{INTRODUCTION}

rickly pear cactus (Opuntia polyacantha L.) is one of the
important crops grown in the arid and semi-arid regions
(Kunyanga et al., 2009 and Nefzaoui and El Mourid, 2010). These fruits are usually consumed by edible freshly or after processing as jelly, jam, juice (Reyes, 2005).

\footnotetext{
${ }^{(1)}$ Assoc. Prof., Ag. Eng. Dept., Fac. of Agric., AL-Azhar Univ.- Assuit.

${ }^{(2)}$ Assoc. Prof., Ag. Eng. Dept., Fac. of Agric., Cairo University.
} 
This fruit is rich in vitamin $\mathrm{C}$ and proteins, low in fat with high calcium, phosphorus and iron content. The extracted pigments from fruits are used as additives in different agro-industry such as food, cosmetic and pharmaceutical preparations (Dehbi et al., 2014). Also, seed and peel can be formulated into number of commercial food product (Mobhammer et al., 2006).

Egypt cultivated four common varieties is about 3116 feddan which produce about $244.2 \mathrm{Gg}$. The productivity is about $10.09 \mathrm{Mg} \mathrm{fed}^{-1}$ (CAAES, 2005, and EAS, 2012).

Harvesting prickly pear fruits are very complicated operation which is still being picked by hand grasp. There are two hand-harvesting techniques. In the first method, the picker grabs the ripe fruit and detaches it from the cactus pad by twisting it off gently, taking care not to damage the connection point to the cladode. In the second method, Prickly pear fruits are harvested by rotating fruit more than $90^{\circ}$ applying pressure and detaching it using a sharp knife (Cantwell, 1995, Ochoa et al., 1997 and Durán-García, 2013). Picking fruits are done in the day early by labours which wearing a plastic glove or thick rubber gloves with special lather cloths for own heads protection as well as to avoid the excessive annoyance of the fine hair and spines that come away from the found on the outer surface of fruits (Ingles, 2010).

Manually harvested of prickly pear fruits are highly perishable and prone to deterioration caused by mechanical damage during harvesting which create sites for establishment and outgrowth of the spoilage microbes. Whereas, microbial spoilage is one of the major causes of quality loss in fresh fruits. The fruits were suffered from mechanical damage due to the finger pressure of labour hands (Corbe et al., 2004).

Many researchers tray to solve the mechanical picking of prickly pear fruit such as $\boldsymbol{A b d} \boldsymbol{E} \boldsymbol{l}$ - Ghany et al. (2015) that developed a hand tool to pick prickly pear fruit to reduce the microbial spoilage incident during hand picking. Their results indicated that, using developed hand aid has increased productivity about $7.2 \%$ and decreased picking cost about 0.04 L.E kg-1.

Laurel and Kipping (2014) designed an innovative mechanism which is operated by a pneumatic system for creating a vacuum pressure inside a 
hose. When sucking, a yielding doughnut made of a thin flexible rubber placed at hose's end performs a gentle but firm grabbing rounding of the fruit, so bending tunas for cutting is easier and safer.

Duran-Gareia et al. (2016) developed a picking arm to harvest prickly pear fruits and analyzed the possibility of building a tool that meets the characteristics sufficient for good harvest. Field studies which were fundamental to the design, such studies were obtained measurements and tests of strength, which were carried out with instruments properly designed for the type of fruit.

Hahn (2013) developed harvesting prickly pear fruits, which consist a motor driven tool supplied from a photovoltaic system was employed. The device was attached with different blades, and it was tested at different cutting speeds.

The prickly pear fruits are basically oriented towards the fresh market which requires harvested fruits without mechanical damage and assuring that the fruits have a long shelf life suitable for good storage and exporting. Therefore, the main objective of this study is to develop, fabricate and evaluate a mobile mechanical machine for picking prickly pear fruits to maximize labour productivity, and minimize picking cost.

\section{MATERIALS AND METHODS}

The picking machine for harvesting the prickly pear fruits had been locally manufactured and evaluated at the Faculty of Agriculture, Omar El-Mukhtar University, El-Beida - Libya during 2014 summer season.

The main criteria for designing the prototype of mechanical or hand aid tools for picking fruits were: the worker had to be able to separate the fruit without hand touching, less damage, increasing harvesting productivity, low weight, simple to use, safe to operate, simple design, and low maintenance costs (Hipolito and Dietnor, 2011).

\section{Dimensions of the prickly pear tree and plantation site}

An important aspect before designing the machine is to know the characteristics of the plantation (length, width and distance between rows) of the prickly pear tree. Fig. (1) shows the row has dimensions to allow the free circulation of trucks. 


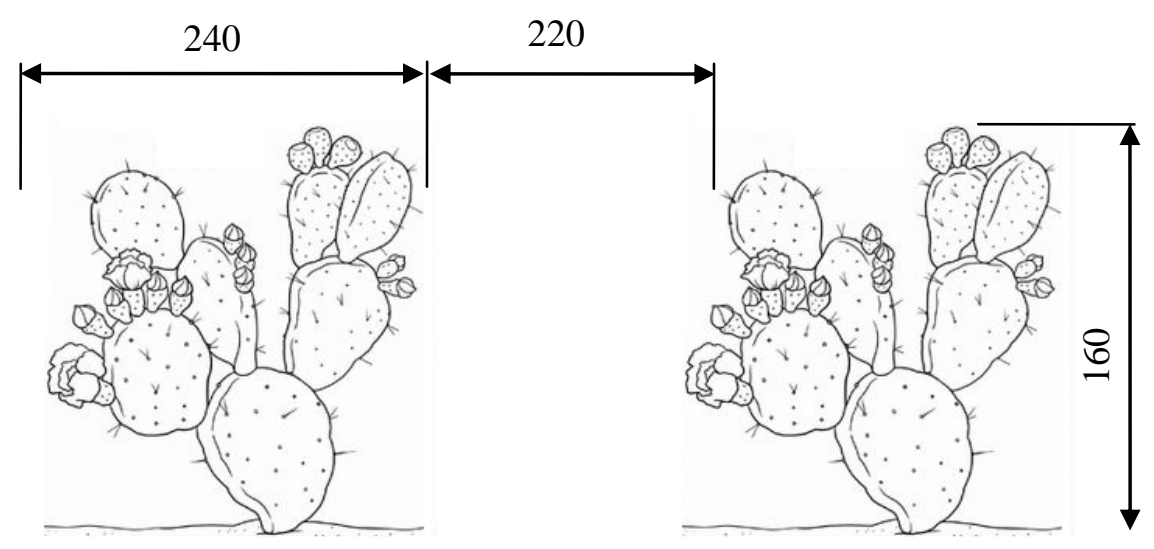

Fig. (1): The dimensions of the tree and space between rows $(\mathrm{cm})$.

\section{Physical and mechanical properties}

A sample of 100 mature fruits was collected randomly to measure the main important fruits physical and mechanical properties which related to the picking machine design and fabrication. Fruits rubbing under running tap water to removed glochides on the peel surface and then drained on tissue paper. The some physical and mechanical properties of prickly pear fruit were studied that ere related to cutting process.

\subsection{Physical properties}

Three axial dimensions (length, width, and thickness), mass and volume were measured. From the previous recorded physical properties data could be obtain, solid density according to Mohsenin (1986).

\subsection{Static coefficient of friction}

The static coefficient of friction of prickly pear fruit against galvanized metal was determined at ripping stage and moisture content of $80.2 \%$ w.b. A device was used for the determination of the friction coefficient as shown in figure (2) according to Ibrahim (2008). The static coefficient of friction was calculated as follows:

$$
\mu=\frac{F_{T}-F_{E}}{W}
$$

Where

$\mu \quad$ : Coefficient of static friction.

$\mathrm{F}_{\mathrm{T}} \quad$ : Force required to start motion of filled carriage, $\mathrm{N}$. 
$\mathrm{F}_{\mathrm{E}} \quad$ : Force required to start motion of empty carriage, N.

W : Vertical weight, $\mathrm{N}$.

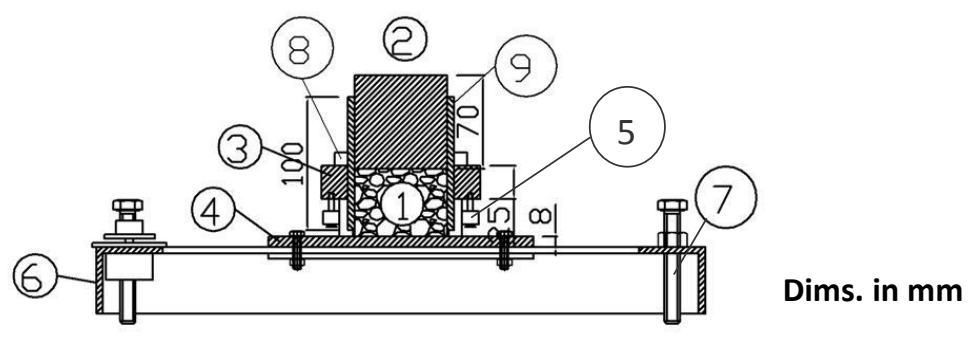

1-Sample

2- Piston (vertical loads)

3- Carriage

4- Sliding surface

5- Rolling wheels

6- Base

7- Adjustable screw

8- Adjustable nut

9- Cylinder

Fig. (2): The device used for measuring the friction force.

\subsection{Shear force and detachment shear force of fruit}

An important of information needed to design the machine for harvest of prickly pears is the shear force required to detach a fruit from the cactus pad and the shear force of the fruit. The shear force test was carried according to $(A S A E, 1999 b)$. The forces were measured by a digital force gauge (Nidec- Shimpo- Corporation, Japan) supported by the stand (Fig. 3). A $3 \mathrm{~mm}$ thickness of knife was used. The maximum value of force $\mathrm{F}(\mathrm{N})$ causing shear of the fruit was recorded.

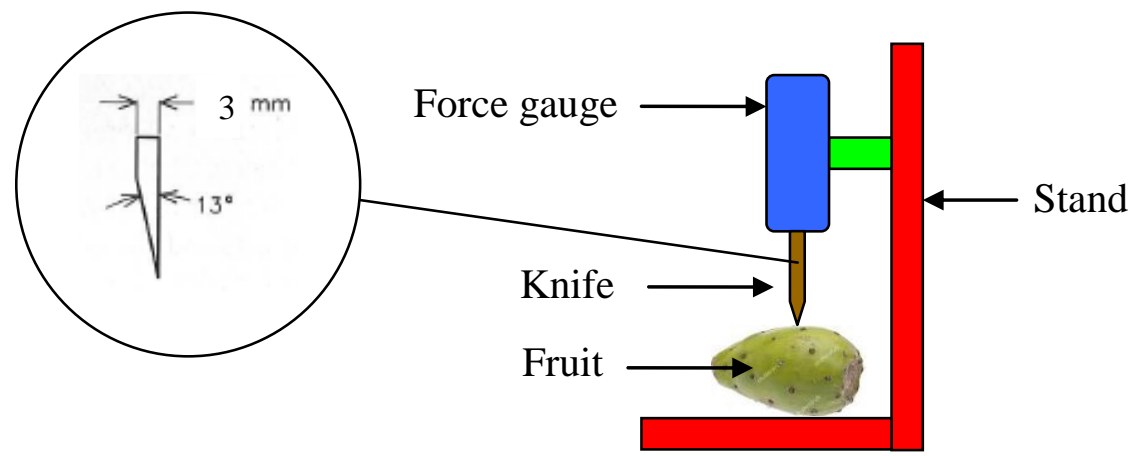

Fig. (3): Test device used to measure shear force

\section{Developed picking machine}

The manufactured picking machine for harvesting the prickly pear fruits consists of the following main parts: a) Cutting mechanism, b) Orientation device, c) Fruits collecting mechanism, and d) Power unit. 


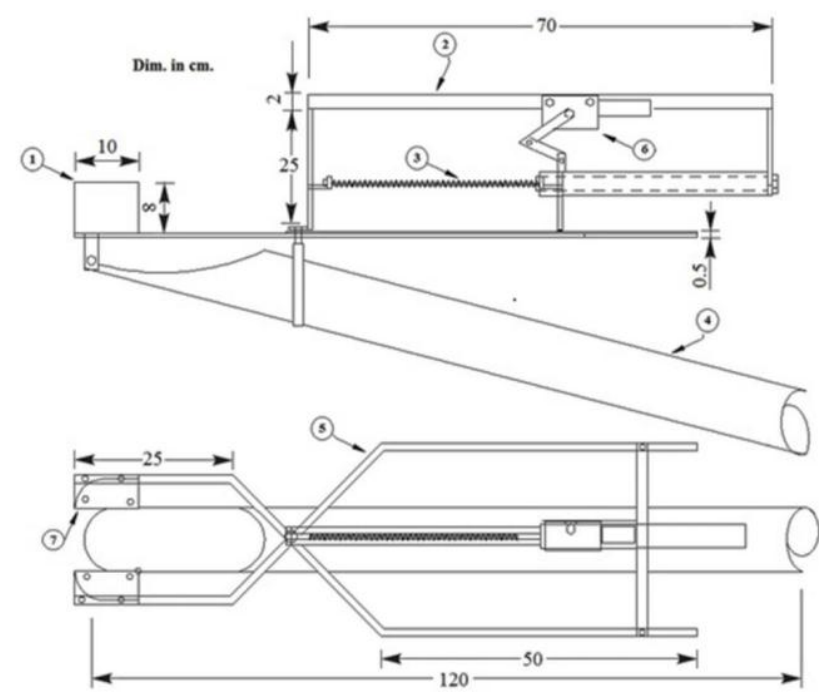

1- Orientation device

3- Compression spring

5- Movable structure

7- Cutting mechanism

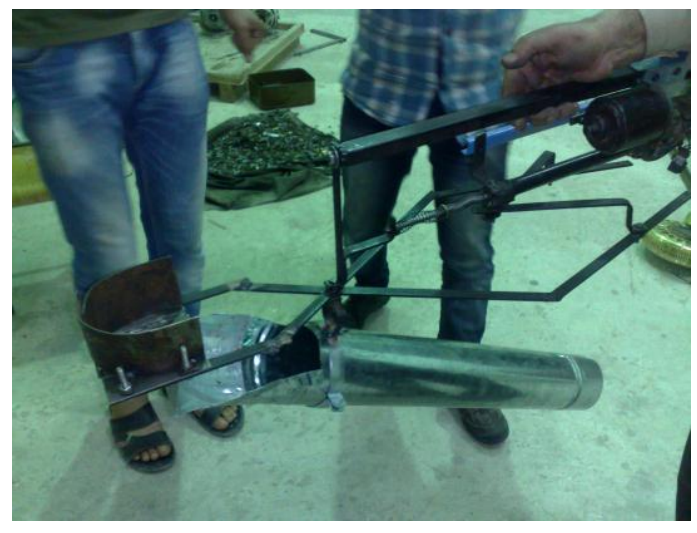

2- Fixed chassis

4- Transport device

6- Electric motor

Fig. (4): The developed picking machine of the prickly pear fruits.

\section{a) Cutting mechanism}

The cutting mechanism is designed to operate by electrical motor (DC) or manual. It consists of carrying hand, fixing chassis, cutting blade and arms. The carrying hand was fabricated from squared iron bar with $5 \mathrm{~mm}$ thickness and $70 \mathrm{~cm}$ length. The cutting blades were fabricated from steel with $12 \mathrm{~mm}$ width, $100 \mathrm{~mm}$ length and $5 \mathrm{~mm}$ thickness. The cutting mechanism is fixed together like the scissors, which produce a horizontal reciprocating motion, as shown in Fig. (4).

Required power: scissors shears is an example of lever class 1. It consists of two levers linked together by bolt and screw (Point o) as a fulcrum. The forces located on the mechanism were analyzed to deduced required force for operating the machine, as shown in Fig. (5).

Fig. (5) shows distribution forces on the machine mechanism where: 
$\mathrm{F}_{\mathrm{a}}$ - required shear force that must be applied at knife (equals Max. shear force to detach fruit $=29 \mathrm{~N}$ ). $\mathrm{F}_{\mathrm{b}}$ - required force that must be applied at handle. $\mathrm{F}_{\mathrm{C}}$ - required force that must be applied at slider.
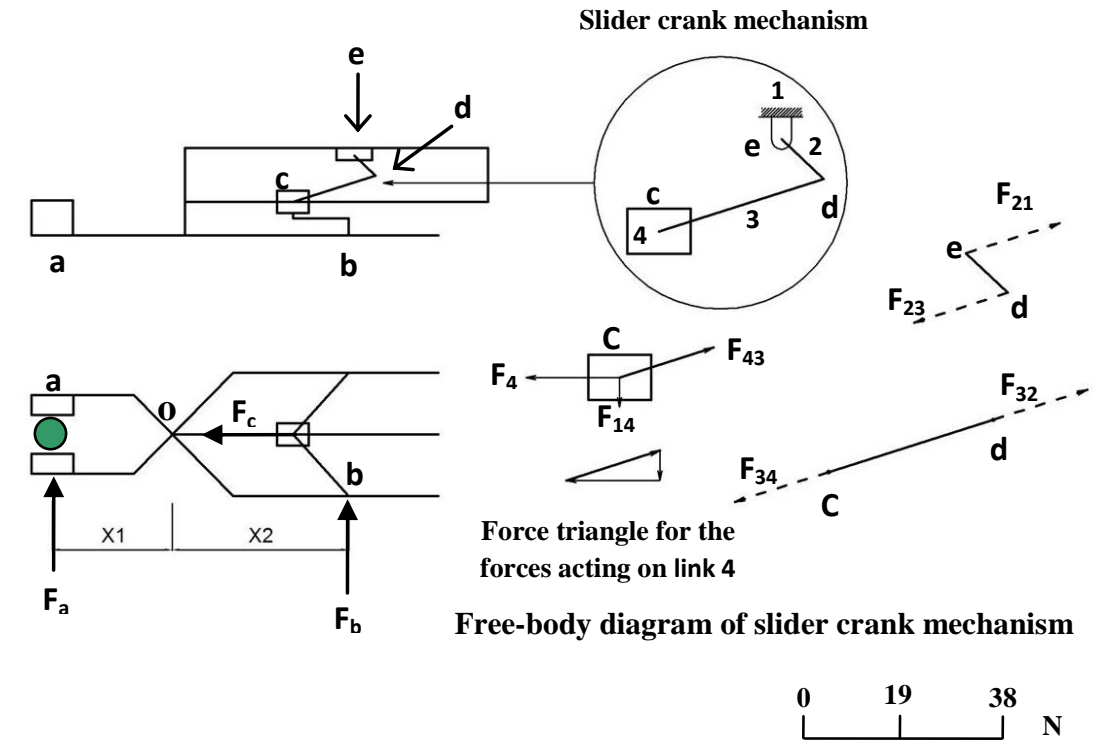

Fig. (5): Distribution forces of the picking machine mechanism.

The different forces were calculated as the following:

1- Calculate the Fb: So, by taking moments about Point $\mathrm{O}$

$\mathrm{M}_{\mathrm{O}}=(\mathrm{Fa})\left(\mathrm{x}_{1}\right)-(\mathrm{Fb})\left(\mathrm{x}_{2}\right)=0$

2- $\mathrm{F}_{\mathrm{C}}$ - it is required force to move link $\mathrm{cb}+$ spring resistant $\mathrm{R}$.

3- Spring resistant (R): The maximum force for compressing spring calculated according to ASME code equation as follow:

$$
R=\frac{G \mathrm{~d}^{4}}{8 \mathrm{n} \mathrm{D}^{3}}\left(L_{\text {free }}-L_{\text {soild }}\right)
$$

Where

$\mathrm{R} \quad$ : Maximum force for spring at solid, $\mathrm{N}$.

G : Modules of rigidity, N.mm ${ }^{-2}$.

E : Modules of elasticity, N. $\mathrm{mm}^{-2}$.

d : Spring wire diameter, $\mathrm{mm}$.

n : Number of active coils.

D : Mean coil diameter, $\mathrm{mm}=\left(D_{o}-D_{I}\right) / 2$.

$\mathrm{D}_{\mathrm{O}} \quad$ : $\quad$ Outer diameter for coil, $\mathrm{mm}$. 
$\mathrm{D}_{\mathrm{I}} \quad: \quad$ Inner diameter for coil, $\mathrm{mm}$.

$\mathrm{L}_{\text {free }} \quad$ : Spring free length, $\mathrm{mm}$.

Lsoild : Spring solid length, $\mathrm{mm}$.

4- The force $\mathrm{Fc}=29 \mathrm{~N}$. By drawing the forces triangle for the forces acting on slider $(\mathrm{C})$, it can get the fore acts on the crank of motor (equals $30 \mathrm{~N}$ ). It can calculate the moment that should is applied by the electrical motor $=\mathrm{F} \times$ length of the link $2=3 \mathrm{~N}$.m.

The required power $(\mathrm{P})$ was calculated by the following equation:

$$
P=\frac{M_{t} \times 2 \pi N}{60}
$$

Where

$\mathrm{P} \quad$ : The required power, $\mathrm{W}$.

$\mathrm{M}_{\mathrm{t}} \quad$ : Torsional moment, $\mathrm{N}-\mathrm{m}$.

$\mathrm{N} \quad$ : Speed of driving link, rpm.

From the previous equation the required power $(\mathrm{P})$ was calculated as $\mathbf{2 0}$ watt.

\section{b) Orientation device}

The orientation device (Fig. 6) was fabricated from a light- weight steel sheet with $0.4 \mathrm{~mm}$ thickness and formed in the circular to suit the fruit shape. The orientation device was fixed upper the cutting blades to prevent the fruit from falling to the outside after cutting.

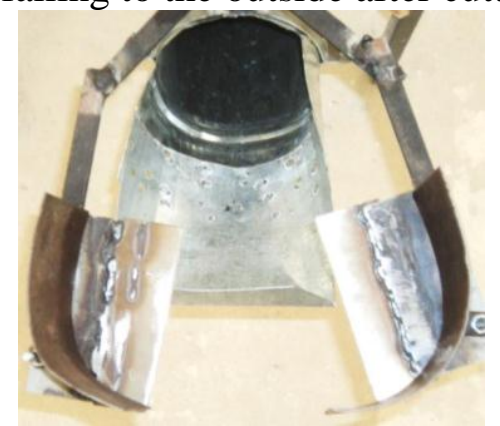

Fig. (6): Cutting blades and orientation device of the developed picking machine.

\section{c) Fruits collecting mechanism}

It consists of fruit receiving/transporting tube and fruit collecting to the mobile fruit collecting basket. It was fabricated from a light- weight steel 
sheet with $0.4 \mathrm{~mm}$ thickness and formed as a cylinder with external diameter of $10 \mathrm{~cm}$ and $120 \mathrm{~cm}$ length. The upper end of fruits receiving tube of the cylinder is such funnel with large reception area. The transport cylinder was equipped with flexible mechanism to control its length and change the tilt angle of the transport cylinder to suit physical fruits properties and facilitate fruit movement inside the inner diameter of transport cylinder which easily allow for maximum fruit diameter to receive basket at the end of transport cylinder (Fig. 7).

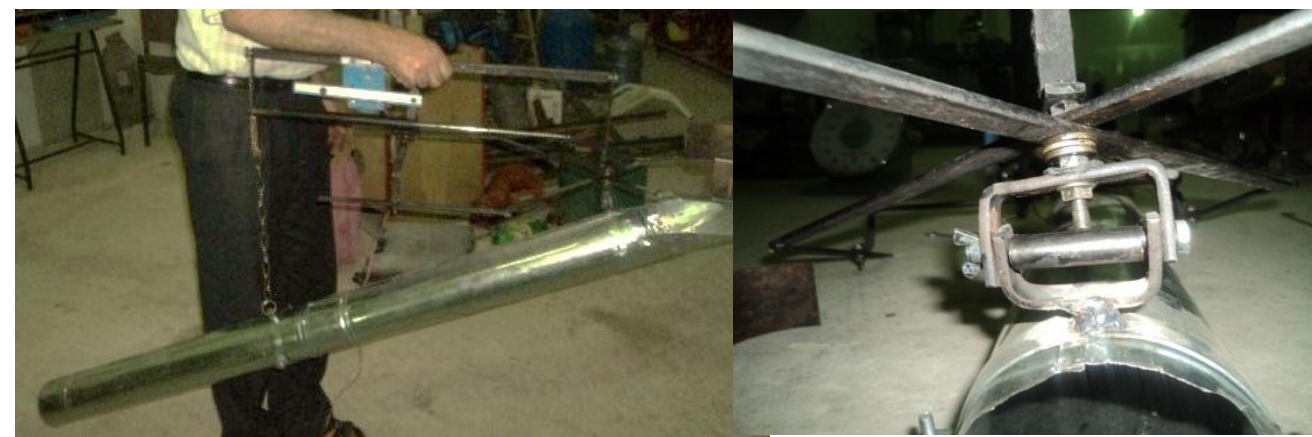

Fig. (7): Cylindrical transport device of the developed machine.

\section{d) Power unit}

The setup of the fabricated picking machine was equipped with two operating power sources. One of them is manually by worker hands and the other is mechanically by electric motor. A small- sized electric motor (DC) is used to operate the picking machine using a dry battery. A mechanical mechanism with crank arm was used to convert the rotational motion of electric motor shaft to linear reciprocating motion to operate cutting blades mechanism as shown in Fig. (8).

Electrical source and operation circuit: a battery (12 V - $70 \mathrm{Ah})$ was used as DC source to operate the linear DC motor through electrical wires passing inside pipes of telescopic carrier, while the operation switch was fixed on the lower pipe of the frame carrier in a suit place for operator the machine (Fig. 8).

Working theory: The operator selected the mature fruit on the tree and detected it by the picking machine by adjusting the two wings of cutting mechanism around the fruit, then switched on to connect the DC current to operate the mechanism. Consequently, the cutting mechanism detaches 
the fruit and dropped it to the fruit receiving tube. After filling the mobile basket with fruits, the operator move and empty it in the fruit boxes.
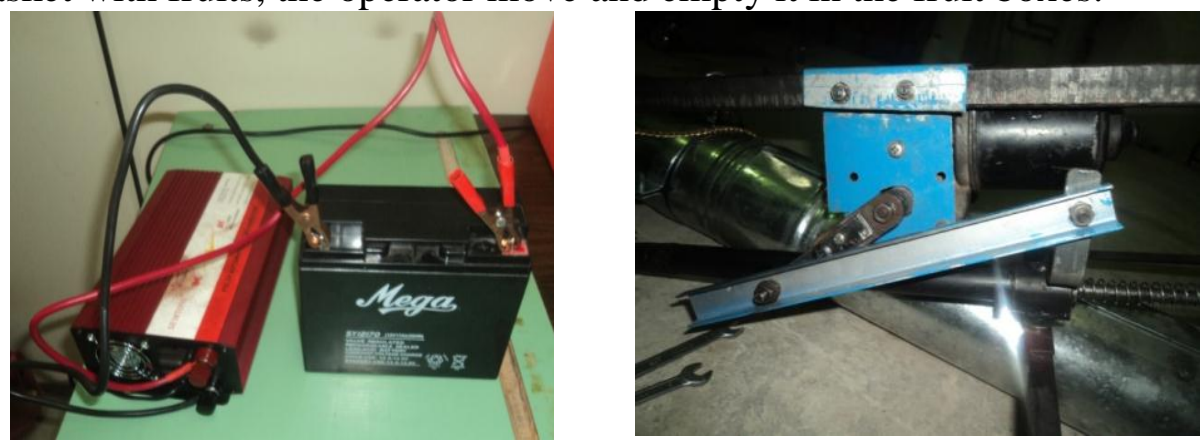

Fig. (8) Power unit and reciprocating mechanism of the developed machine.

\section{Evaluation criteria}

According to literature data $(A S A E, 1999$ a; Srivastava et al., 2006; CIGR, 1999), the performance of developed mechanisms was possibly measured by picking productivity, mechanical fruit damage, consumed energy and picking cost.The performances evaluation of prickly pear fruits picking machine was done in this study under the following variables as shown table (1).

Table (1): Experimental plan for evaluating the machine.

\begin{tabular}{ll}
\hline Variables & Levels \\
\hline Picking methods & hand, mechanical \\
Machine operating & manual, mechanical \\
Crank speed for mechanical operating & 40,60 \\
(rpm) & \\
\hline
\end{tabular}

\subsection{Picking productivity}

The total mass of picking fruits using mechanical and manual operated for picking machine was recorded and compared with hand picking. The total picking time includes selecting and detaching fruit, collecting detached fruits in the basket. In addition to, the time required for moving machine between prickly pear trees inside the field. The productivity of mechanical operated picking machine was calculated as follows:

$$
\mathrm{P}_{\mathrm{m}}=\frac{\mathrm{W}}{\mathrm{T}}
$$


Where

$\mathrm{P}_{\mathrm{m}}$ : Productivity, $\mathrm{kg} \mathrm{h}^{-1}$.

$\mathrm{W}$ : Mass of collecting fruit, $\mathrm{kg}$.

$\mathrm{T}$ : Total picking time, $\mathrm{h}$.

\subsection{Fruit damage}

Methods of measuring fruit damage include visual inspection in which the fruit scale appears broken to the naked eye (Srivastava et al., 2006). The quality of picked peach fruits was evaluated by calculating the fruits percentage having visible mechanical damage due to fall fruits out of receiving tube/basket or cutting by developed machine parts. Fruit damage was calculated by the following equation:

$$
F d=\frac{m d}{m t} \times 100
$$

Where

$\mathrm{F}_{\mathrm{d}} \quad$ : fruit damage, $\%$

$\mathrm{m}_{\mathrm{d}} \quad$ : Total mass of fruit damage, $\mathrm{kg}$

$\mathrm{m}_{\mathrm{t}} \quad$ : Total mass of fruit picking, $\mathrm{kg}$

\subsection{Consumed energy}

With hand picking, the required power calculated as human work output where the physical power output is approximately $0.075 \mathrm{~kW}$ sustained for an 8-10 hour work day according to $\boldsymbol{C I G R}$ (1999). With picking machine (manual operated), the required power calculated as force required to work the machine multiple by the distance movement and divided by the worked time. With picking machine (operated by electrical power), the required electric power under working load (RP) was calculated as Chancellor (1981) by the following equation:

$$
\mathrm{RP}=\mathrm{V} \times \mathrm{I} \times \cos \theta
$$

Where

RP : The required power for operate the machine, watt.

$\mathrm{V} \quad$ : $\quad$ Potential difference, Voltage (I phase $=12$ voltage).

I : Line current strength, Amperes.

$\cos \theta \quad$ : Power factor (0.64).

A digital clamp meter and voltmeter were used for measuring current intensity and voltage respectively. 
The consumed energy (CE) is specific power per unit capacity; it was calculated by using the following equation:

$$
\text { Consumed energy }\left(\mathrm{kW} \cdot \mathrm{h} \mathrm{kg}^{-1}\right)=\mathrm{RP} / \mathrm{P}_{\mathrm{m}},
$$

\subsection{Picking cost}

Machine cost was determined using the fixed costs and variable costs according to Srivastava et al. (2006). The hand picking cost ( $\left.\mathrm{L}_{\mathrm{E}} \mathrm{Kg}^{-1}\right)$ was calculated based on the labor daily salary and its picking productivity.

However, the picking cost using picking machine (L.E $\mathrm{Kg}^{-1}$ ) was calculated based on fixed cost and variable cost of the picking machine. The operational cost was determined using the following equation:

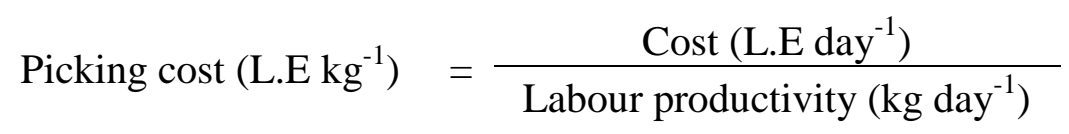

\section{RESULTS AND DISCUSSIONS}

\section{Prickly pear fruit properties}

Minimum (Min.), maximum (Max.), average (Av.) values and standard deviation (SD) of the physical and mechanical properties for prickly pear are summarized in table (2).

\begin{tabular}{|c|c|c|c|c|}
\hline \multirow{2}{*}{ property } & \multicolumn{4}{|c|}{ Value } \\
\hline & Max. & Min. & Av. & SD. \\
\hline & \multicolumn{4}{|c|}{ Physical } \\
\hline Fruit length, mm & 77.31 & 57.22 & 69.98 & 11.09 \\
\hline Fruit upper diameter, mm & 40.25 & 23.30 & 33.3 & 3.31 \\
\hline Fruit middle diameter, $\mathrm{mm}$ & 56.6 & 41.78 & 48.50 & 2.53 \\
\hline Fruit lower diameter, mm & 30.15 & 18.67 & 21.45 & 3.97 \\
\hline Fruit mass , $\mathrm{g}$ & 126.2 & 52.7 & 88.44 & 16.65 \\
\hline Fruit actual volume, $\mathrm{cm}^{3}$ & 140.9 & 70.5 & 90.53 & 19.17 \\
\hline \multirow[t]{2}{*}{ Fruit solid density, $\mathrm{g} \mathrm{cm}^{-3}$} & 1.30 & 0.70 & 0.98 & 0.14 \\
\hline & \multicolumn{4}{|c|}{ Mechanical } \\
\hline Static coefficient of friction & 0.357 & 0.533 & 0.433 & 0.14 \\
\hline Fruit shear force, $\mathbf{N}$ & 15.72 & 6.34 & 8.95 & 3.51 \\
\hline $\begin{array}{l}\text { Fruit shear force } \\
\text { detachment, } \mathbf{N}\end{array}$ & 29 & 12.3 & 18.50 & 10.33 \\
\hline
\end{tabular}

Table (2): Physical and mechanical properties of prickly pear fruit. 


\section{Picking productivity}

Fig (9) shows the picking productivity of prickly pear fruits using mechanical and manual operated picking machine comparing with hand picking method. By using mechanical picking machine gives an average productivity of $50,57,32 \mathrm{~kg} \mathrm{~h}^{-1}$ at $40 \mathrm{rpm}$ speed, $60 \mathrm{rpm}$ speed and manual operating, respectively. The hand picking productivity is $21 \mathrm{~kg} \mathrm{~h}^{-}$ ${ }^{1}$. The results cleared that the productivity increased by about $14 \%$ due to increase the picking speed from 40 to $60 \mathrm{rpm}$. The average productivity of developed machine at $40 \mathrm{rpm}$ and $60 \mathrm{rpm}$ increased about $138.1 \%$ and $171.4 \%$ comparing with using hand picking method.

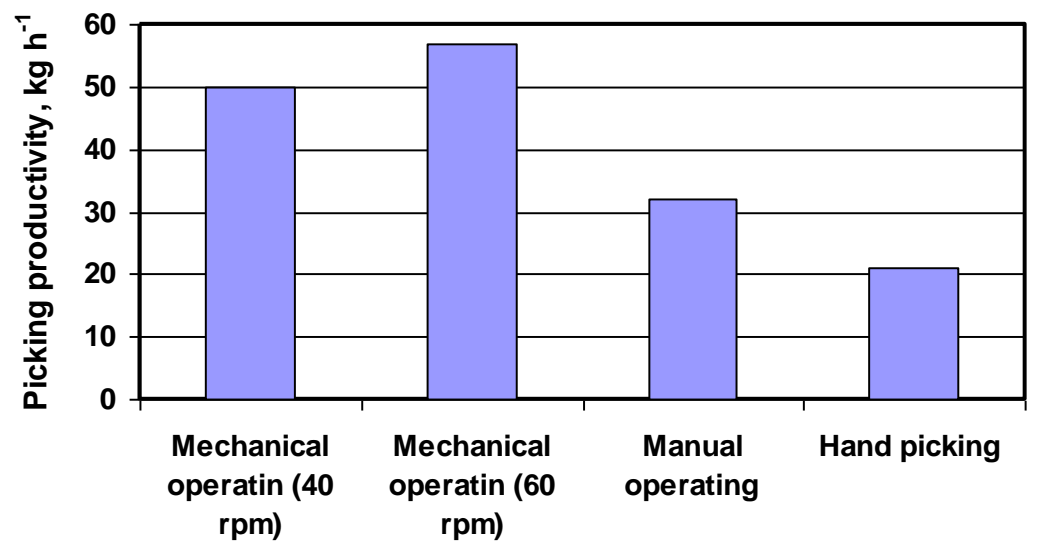

Picking methods

Fig. (9): Effect of picking method on picking productivity.

\section{Fruit damage}

The obtained results of fruit damage during applied the mechanical or manual picking machine comparing with hand packing method are shown in Fig. (10). The results cleared that the fruit damage due to use the developed machine at $40 \mathrm{rpm} 60 \mathrm{rpm}$ and manual operating decreased about $42.4 \%, 30.3 \%$ and $51.5 \%$, respectively comparing with hand picking method.

\section{Consumed energy}

Fig. (11) shows the consumed energy of prickly pear fruits using mechanical and manual operated picking machine comparing with hand picking method. 


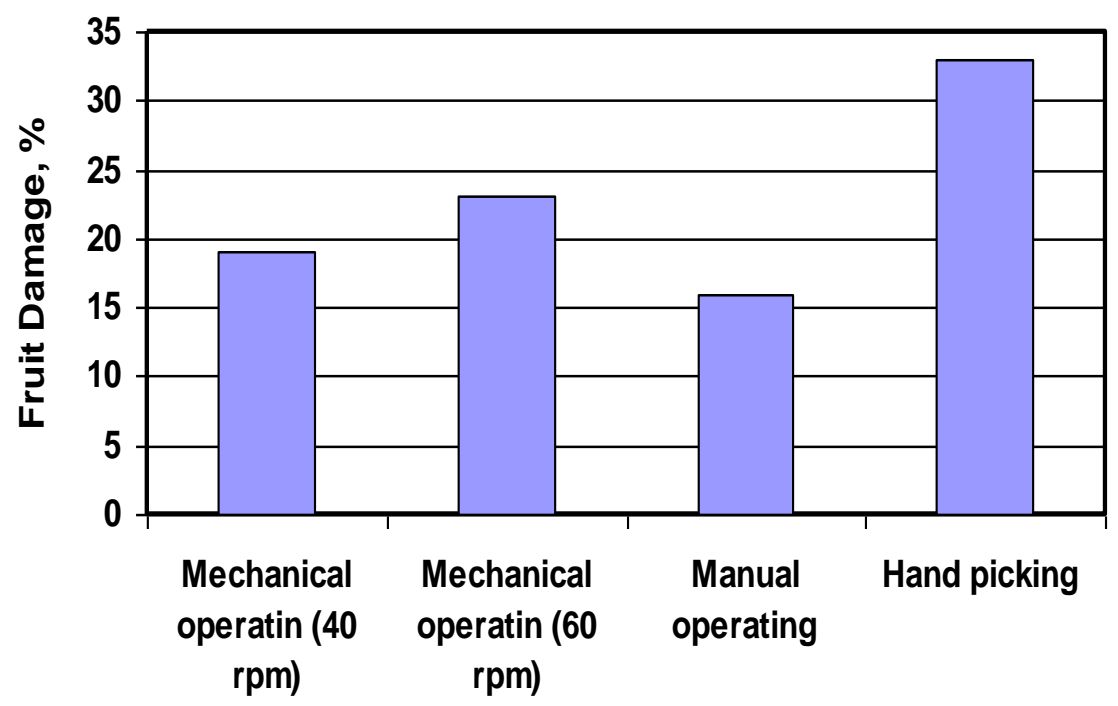

Picking methods

Fig. (10): Effect of picking method on fruit damage.

By using mechanical picking machine gave an average consumed energy of 0.25 and 0.33 W.h kg-1 at $40 \mathrm{rpm}$ speed and $60 \mathrm{rpm}$ speed, respectively. By using manual picking machine and hand picking gave an average consumed energy of 0.78 and $3.57 \mathrm{~W} . \mathrm{h} \mathrm{kg}^{-1}$, respectively. The consumed energy increased by about $32 \%$ due to increasing the picking speed from 40 to $60 \mathrm{rpm}$. Also, the consumed energy of picking machine at $40 \mathrm{rpm} 60 \mathrm{rpm}$ and manual operating decreased by about 13.28, 9.82 and 3.85 times, respectively comparing with hand picking method. It could be noticed that the lowest values of consumed energy were obtained at mechanical operating with $40 \mathrm{rpm}$, however the highest values of consumed energy were obtained at hand picking.

\section{Picking cost}

Fig. (12) shows the estimated picking cost using mechanical and manual operated comparing with hand picking method for picking prickly pear fruits. The picking costs are $0.33,0.29,0.41,0.47 \mathrm{~L}^{\mathrm{E}} \mathrm{kg}^{-1}$ at $40 \mathrm{rpm}$ speed, $60 \mathrm{rpm}$ speed, manual operating and hand picking, respectively. Also, the picking costs of picking machine at $40 \mathrm{rpm} 60 \mathrm{rpm}$ and manual 
operating decreased by about $29.8,38.3$ and $12.8 \%$, respectively comparing with hand picking method.

From the previous results, the most suitable working of the developed machine that realize acceptable productivity, low fruit damage, low consumed energy and low cost at $40 \mathrm{rpm}$ and $60 \mathrm{rpm}$.

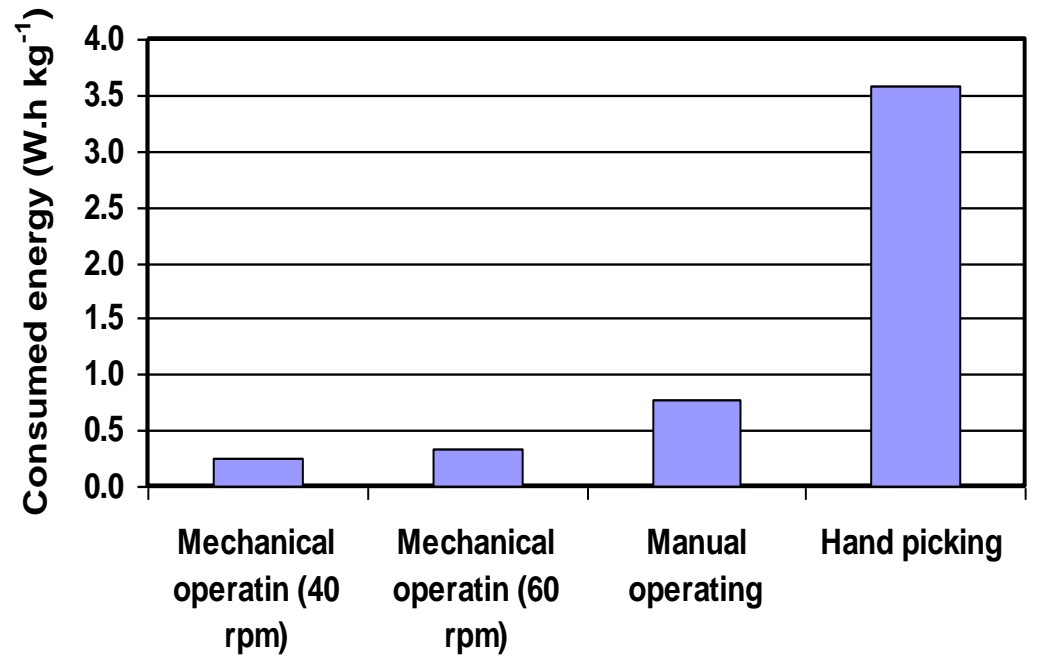

Picking methods

Fig. (11): The effects of picking methods on consumed energy.

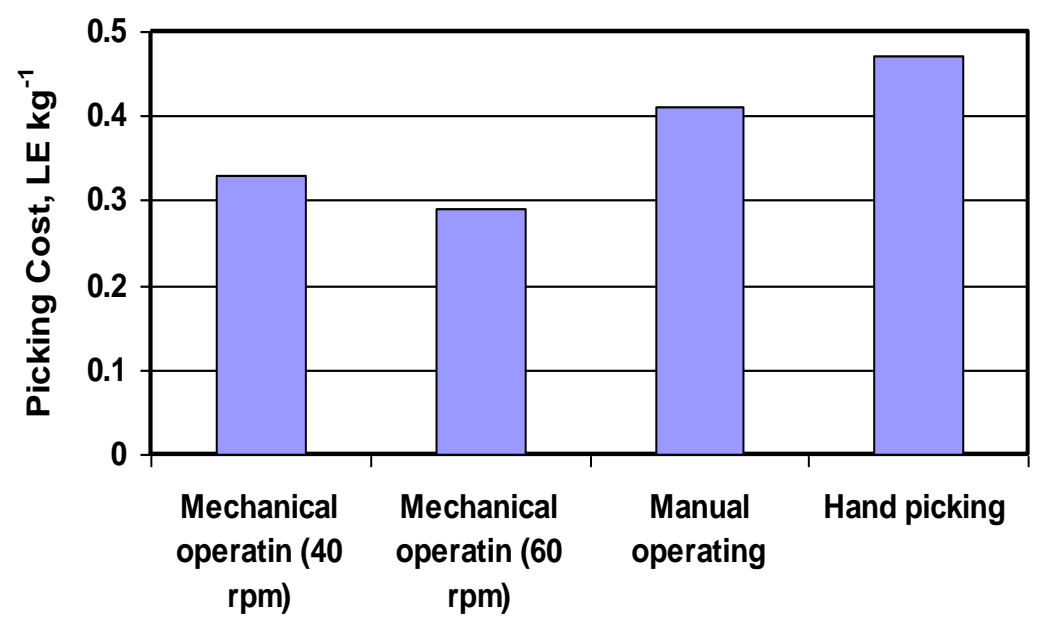

Picking methods

Fig. (12): Effect of picking method on picking cost. 


\section{CONCLUSIONS}

The physical and mechanical properties of prickly pear fruits were studied for developed a picking machine. The machine was design and fabricated and evaluated. Field test results show that the developed picking machine is easy to use with less damaged. By comparing with hand picking method, productivity with developed picking machine increased by about $138.1 \%$, the damage of fruit decreased by about $43 \%$, consumed energy decreased by 13.28 times and the picking costs decreased by about $29.8 \%$.

\section{REFRENCES}

Abd El - Ghany, M. A. Horia, Ismail, K. Nahed and N. M. El- Bialee. 2015. Developed hand tool to pick Prickly pear fruit. International Journal of Advanced Research Volume 3, Issue (5): 1307-1315.

ASAE Standards. 1999 a. Terminology for combines and grain harvesting. Standard ASAE NO: S343.3. St. Joseph, Mich. ASAE:192-196.

ASAE Standards. S459 MAR98. 1999 b. Shear and three-point bending test of animal bone. St. Joseph, MI: ASABE.

CAAES - Central Administration for Agricultural Extension Services. 2005. Cultivated and product Prickly pears. Agric. Res. Center (ARC). Ministry of Agric. and Land Reclamation. Cairo. Egypt. Bulletin No., 993. (In Arabic)

Cantwell, M. 1995. Post - harvest management of fruits and vegetable stems. In :Baebera G ., Ingles, P., Pimlenta - Barrios (eds). Agro ecology cultivation and uses of cactus pear. FAO Plant Production and Protection Paper.Food and Agriculture Organization of the United Nations. Rome, Italy. No.132:120-143.

Chancellor, W. J. 1981. Substituting information for energy in agricultural. Trans. ASAE Paper No. 0001- 2351.

CIGR. 1999. Handbook of agricultural engineering. Volume III. Plant Production Engineering. The International Commission of Agricultural Engineering. Published by the ASAE. 
Corbo, M. R., C. Altieri., D. D'Amato., D. Campaniello., M. Del Nobole., M. Sinigaglia., 2004. Effect of temperature on shelf life and microbial population of lightly processed cactus pear fruit. Postharvest Biol. Tech., 31 (1):94-104.

Dehbi Fatima., H. Aziz., O. Aziz, E. Hicham., and J. Abderrahim. 2014. Physicochemical characteristics of moroccan prickly pear juice (Opuntiaficusindica L.). International Journal of Emerging Technology and Advanced Engineering, 4 (4): 300-306.

Durán-García, H. M., R. Romero-Méndez, J. L. M. P. Delgado, O. G. García, and C. I. J. Delgado. 2013. Development and construction of an arm tool for nonselective harvest of Alfajayucan type prickly pear. Journal of Food, Agriculture \& Environment, 11(2), 358-362.

Durán-García, H., O. Guarneros-García, C. Jiménez Delgado, E. Rossel-Kipping, J. Pulido-Delgado. 2016. Structural design of a mechanical arm for harvest of cactus pear type Alfajayucan. Journal of Applied Research and Technology 14 . Pp: 140-147.

EAS. 2012. Bulletin of estimates agricultural income. (In Arabic). Economic Affairs Sector (EAS). Ministry of Agric. and Land Reclamation. Cairo. Egypt, (22): 54.

Hahn, F. 2013. Photovoltaic prickle pear harvesting tool. Natural Resources, 4: 263-265.

Hipolito, O. L. and R. K. Dietnor. 2011. Cissing a cactus: mechanical harvesting of Prickly pear. Engineering \& Technology for sustainable world.

Ibrahim M. M. 2008. Determination of dynamic coefficient of friction for some materials for feed pellet under different values of pressure and temperature. Misr J. Ag. Eng., 25(4):1389-1409.

Inglese, P. 2010. Cactus pear, Opuntiaficus-indica L. (Mill.) for fruit production: an overview. CACTUSNET NEWSLETTER.Special Issue. Improved utilization of cactus pear for food, feed, soil and water conservation and other products in Africa Proceedings of 
International Workshop held in Mekelle, Ethiopia, 19- 21 October. Pp:82-92.

Kunyanga. C.N., S. Strum., S. Graham., J. Sipitiek., and J. K. Imungi. 2009. Physico-chemical methods for preservation of opuntia cactus fruit syrup. African Crop Science Conference Proceedings, 9: 333 - 337.

Laurel, H. O. and D. R. Kipping. 2014. Development of a mechanical harvesting aid for prickly pear cactus fruit. Agricultural Mechanization in Asia, Africa, and Latin America- AMA. VOL.45 (2): $65-69$.

Mobhammer, M. R., F. C. Stintzing and R. Carle. 2006. Cactus pear fruits (Opuntia spp): A review of processing technologies and current uses. J. Prof.Assoc. Cactus Dev., 8: $1-25$.

Mohsenin, N. N. 1986. Physical properties of plant and animal materials.Gordon of Breach science publishers, New York.

Nefzaoui, A. and M. El Mourid. 2010. Cacatus pear for soil and water conservation in arid and semi- arid lands. CACTUSNETNEWSLETTER. Special Issue. Improved utilization of cactus pear for food, feed, soil and water conservation and other products in Africa. Proceedings of International Workshop, Mekelle (Ethiopia),19-21 October.117-123.

Ochoa, J., C. Degano., G. Ayrault and M. E. Alonso. 1997. Evaluation of postharvest behavior in cactus pear (Opuntiaficus-indica L. Mill.).Acta Hort., 438: 115-121.

Reyes. A. J. A., J. R. Aguirre and H. M. Hernández. 2005. Systematic notes and a detailed description of Opuntiaficusindica (L.) Mill. (Cactaceae). Agrociencia, 39: 395-408.

Srivastava, A. K., C. E. Goering, R. P. Rohrbach and D. R. Buckmaster. 2006. Engineering principles of agricultural machines. St. Joseph, Mich.: ASAE. 
الملخص العربي

\section{تطوير آلة محمولة لقطف ثمار التين الشوكي}

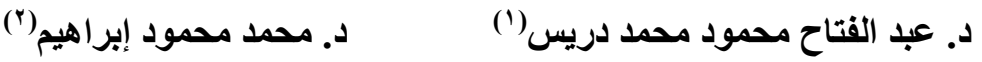

التين الثوكي أحد المحاصيل الهامة التي تتحمل الجفاف ويستخدم في التنمية المستدامة حيث يزرع في المناطق الجافة والثبه جافة. وتسنهلك ثمار ها أما طازجة أو مصنعة في صورة مربات و عصائر كما تستخدم الأصباغ المستخرجة منه في صناعة الأدوية ومستحضر ات التجميل. تبلغ

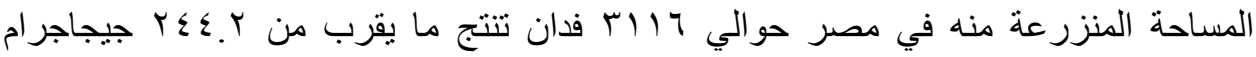

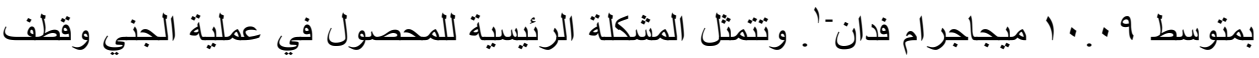
الثمار حيث تنتشر أشو الك ناعمة وكثيفة على المحيط الخارجي للثمار وتزداد حدة الأشوالك مع

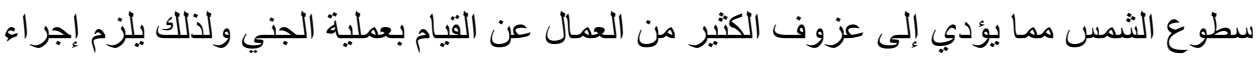
العديد من الترتيبات الخاصة لقطف الثمار مثل ارتداء قفاز ات من المطاط السميك أو أكياس من لتن البلاستيك و التي تنقص من كفاءة العامل وأيضا القيام بعملية القطف في الصباح الباكر وقبل منيل فئل

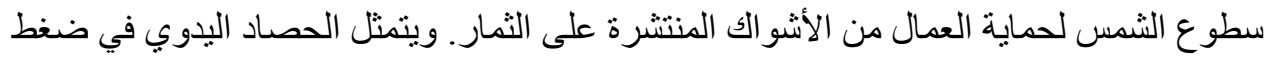

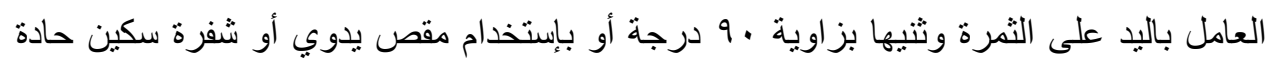

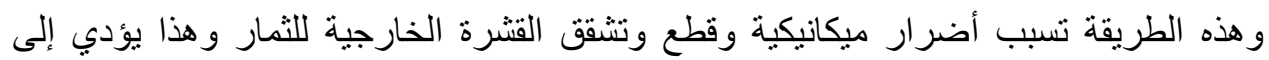

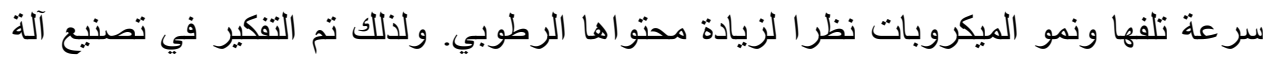
صغيرة محمولة على الكثف للتغلب على مشاكل قطف ثمار التين الشوكي بأقل نسبة من الضرر الميكانيكي.

قد تم در اسة الخصائص الطبيعية والميكانيكية لثمار التين الثوكي للاستعانة بها في تصميم الآلة:

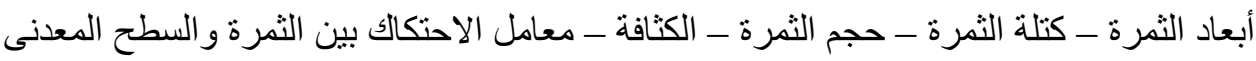
ـ القوة اللازمة لقص الثمرة وفصلها وقوة القص اللازمة لقطع الثمرة نفسها. لآلة المصنعة تتكون من: جهاز القص - جهاز التوجيه - أسطوانة نقل الثمار بعد القطف ـ مصدر القدرة وهو عبارة

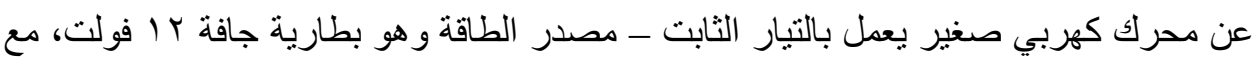

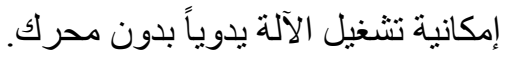

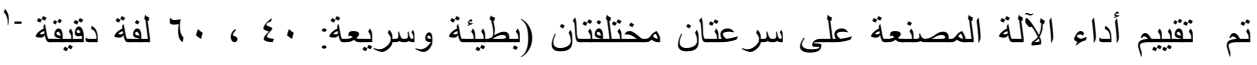
للتشغيل الآلى) و التشغيل اليدوى للآلة مقارنة بالقطف اليدوى. وكانت معايير التقييم كالتالى: الإنتاجية - نسبة الضرر للثمار - الطاقة المستهلكة فى عملية القطف - تكاليف الحصاد.

(') أستاذ الهندسة الزراعية المساعدـ كلية الهندسة الزراعية - جامعة الأزهر - أسيوط. () أستاذ الهندسة الزراعية المساعد- كلية الزراعة ـ جامعة القاهرة. 
وقد بينت الدراسة ما يلي: - ماري

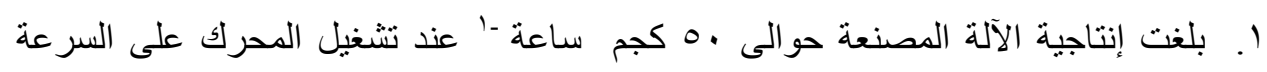

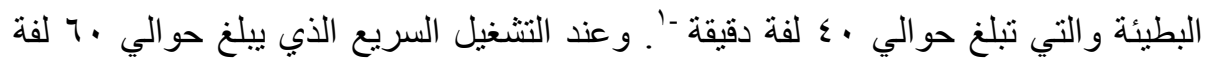

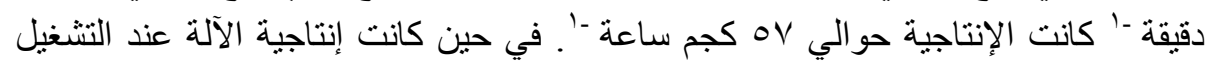

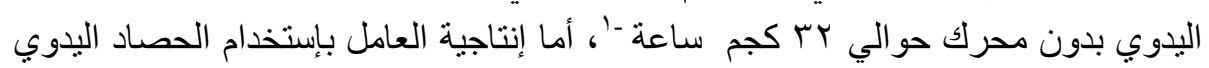

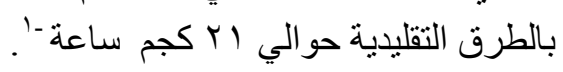

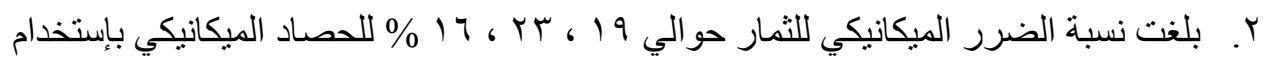

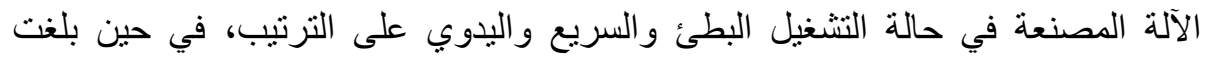
حو الي بr\% عند الحصاد اليدوي بإستخدام العامل.

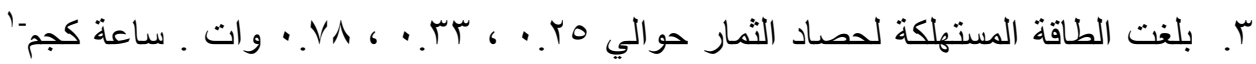

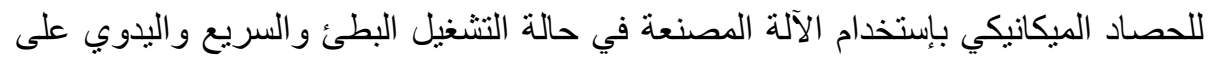

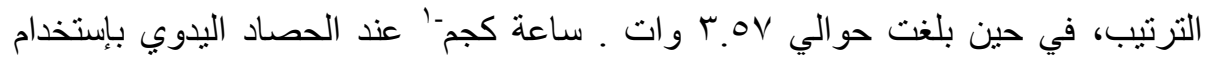

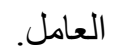

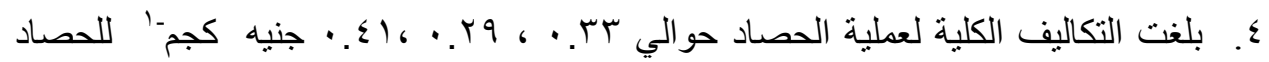

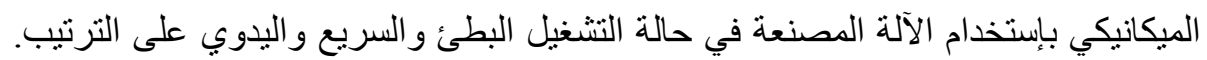

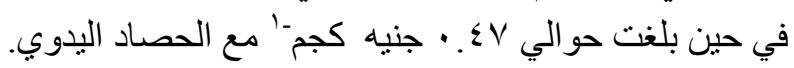
•. ينصح بإستخدام الآلة المطورة فى عملية حصاد التنين الثوكى على التشغيل البطئ أو السريع • . ، . ، لفة دقيقة -'. 